
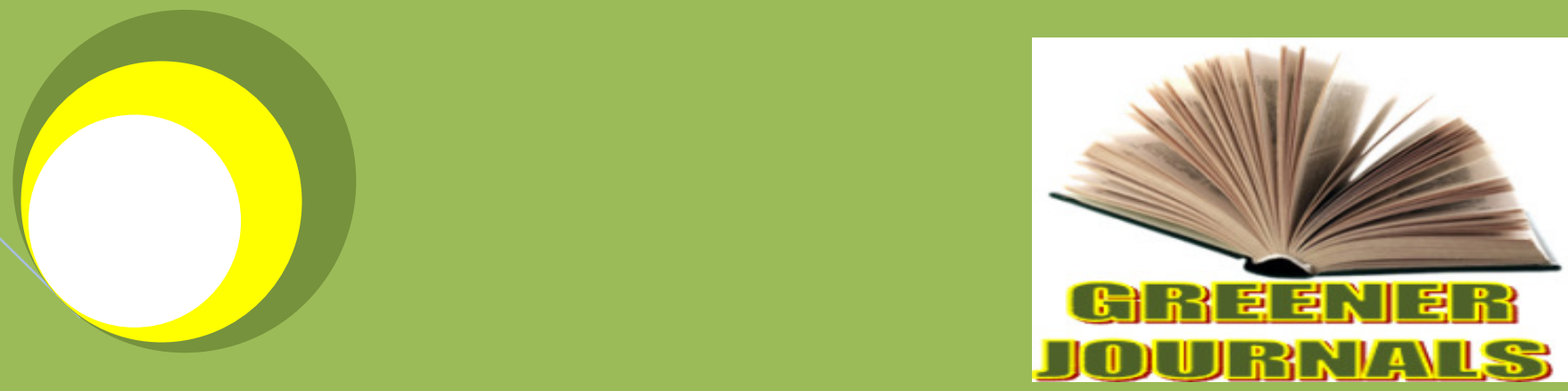

Greenerilournal of Social Sciences GJSS ISSN: 2276-7800 Impact Factor 2012 (UJRI): 0.7863 ICV 2012: 5.99

Relative Incidence of Tenant Eviction in Residential and Commercial Properties in Ilorin Metropolis, Nigeria between 1998 - 2007 By

Ibrahim T. Akogun 


\title{
Relative Incidence of Tenant Eviction in Residential and Commercial Properties in Ilorin Metropolis, Nigeria between 1998 - 2007
}

\author{
Ibrahim T. Akogun \\ Department of Estate Management, Moshood Abiola Polytechnic, Abeokuta, Ogun State, Nigeria. \\ Email: akogun2000@yahoo.com
}

\begin{abstract}
In property management, some reasons would make it imperative to terminate some tenancies so, tenant eviction is almost inevitable. It is a global phenomenon, occurring in all parts of the world, both developing and developed countries. The main thrust of this study is to assess the relative incidence of eviction in residential and commercial properties in Ilorin metropolis. Primary data for this study including records of tenant evictions from residential and commercial properties within the ten-year period were collected by self-administered questionnaires administered on the 16 practising firms of Estate Surveyors and Valuers within Ilorin metropolis during the period covered by the study. There were increasing trend in eviction during the period. Results showed that evictions from residential properties accounted for $67.35 \%$ while commercial properties accounted for $32.65 \%$. The incidence of tenant eviction was higher on residential properties while low income earners residing in tenement and block of flats are mostly affected. The paper provides a basis for comparing the occurrence of evictions from residential and commercial properties with a view to guiding policy makers, property managers and tenants.
\end{abstract}

Keywords: Tenancy, tenant eviction, tenancy determination, property management, llorin.

\section{INTRODUCTION}

The term 'eviction' describes the practice of involuntary removal of person(s) from their homes. It is frequently associated with a range of related terms such as premises recovery, ejection, relocation, dislocation, expulsion and displacement. Although the causes of tenant eviction can be varied, in most instances, it arises as a response of landlord to unruly violation of the lease by tenant. Different methods have also been used in different places. The consequences of eviction are highly disturbing, particularly when we look more closely at its local impacts- on individuals, families and communities (Leckie, 1995; Taribo, 2011; Landlord and Tenant Board, 2012; NCH, 2012 and Moneke, 2009). Also, of great concern is the impending eviction of thousands of families living in various categories of rental properties across the country.

In the same way that today's manufacturers have warranties that go with automobiles, toasters, televisions and other consumer products, landlords are expected by law to provide dwelling units that are fit for their intended purpose. The warranty of habitability overrides any agreement and is implied into all landlord-tenant contracts, oral and written. This obligation starts at the beginning of the rental contract, and since tenants continue to pay rents periodically, landlords are expected to maintain the tenantable condition during the term of the tenancy (Langston, 1951, Powel, 1969). The legal logic then follows that if the landlord fails to provide a "fit" apartment at the beginning or to keep it "fit" during the tenancy, the landlord-tenant contract has been broken, and the tenant is no longer obligated to pay rent. But many questions remain unresolved. If the tenant stops paying rent, must he also move out of the unfit apartment? What if the tenant causes damage or fails to report conditions as they arise? Is there allowance in the law for the fact that apartments (unlike autos, toasters, televisions) are used and sometimes quite old "products"? Or must the landlord provide a "new" apartment for the same low rent agreed upon at the beginning - or while the tenant pays no rent at all? Can the landlord throw out the non-paying tenant by a self-help eviction? Can the tenant, besides not paying rent, threaten to beat the landlord so that he would keep silent? These unresolved questions inevitably lead to conflict and even violence.

A lease is a contract between a landlord and tenant which contains the terms and conditions of the rental. It cannot be changed while it is in effect unless both parties agree (Spitzer, 2003). Property management problems would reduce considerably if all tenants comply with the rules, covenants and conditions of a tenancy. Even where 
this is possible, some other reasons would make it imperative to terminate some tenancies. In property management, tenant eviction is almost inevitable although there are several precautions that may be taken to avoid it. It is a global phenomenon, occurring in all parts of the world, both developing and developed countries (COHRE, 2004).

In Nigeria and particularly in the study area, most tenants, landlords as well as property managers have suffered some degrees of hardship, financial loss, social stigma and disgrace resulting from the problems that could be traced to tenant eviction. Many tenants needlessly suffer grave hardships for lack of knowledge of the protections which the relevant laws confer on them (Moneke, 2009). While tenant eviction raises a lengthy series of human, social, economic and political considerations, this study will examine the practice primarily within the purview of property management. Therefore, the main thrust of this study is to assess the relative incidence of eviction on residential and commercial properties in llorin metropolis. The study analysed the available data on eviction to show clearly the eviction figures for the two categories of properties. The questions attempted by the study include what is the general outlook of tenant eviction in the study area? What is the effect of the eviction incidence? What should be done to discourage or manage the practice of eviction? The paper presents the global meaning of tenant eviction, overview of the study area, methodology used for data collection, data presentation and analysis, summary and conclusion.

\section{Meaning of Tenant Eviction}

The ordinary meaning of eviction is to force somebody to pack out of the house they are living usually permanently and for a stated reason. Its professional meaning is given as "a legal proceeding by a lessor (landlord) to recover possession of property" (Friedman et al, 1997). Both the landlord and tenant have some obligations to respect under the tenancy agreement. Whenever there is a conflict between the landlord and tenant arising from breach of lease terms, eviction may be inevitable especially when other forms of settlement are not feasible (Ojo, 2007). When a tenant fails to comply with the lease agreement, the landlord may seek eviction of the tenant to terminate his rights to use the property. The Wikipaedia (2006) defined eviction as "a legal process by which a landlord forces a tenant to move out of the landlord's property involuntarily and usually permanently". A Landlord who wants to terminate a tenancy in order to recover possession of his property from a tenant for whatever reason must observe due diligence and lawful procedure to achieve his objective. Self-Help is an extra-judicial remedy to enforce or protect a right, where the landlord employs self-help, it must be lawful otherwise he will be criminally liable for his actions (ACN, 2011; MBIE, 2013; Knowsley Council, 2013; Taribo, 2011; Moneke, 2009).

TxLIHIS (2006) refers to eviction as "a lawsuit filed by a landlord to remove persons and belongings from the landlord's property". In Texas law, these are also referred to as "forcible entry and detainer" or "forcible detainer" suits. There are hundreds of cases filed every day with Texas justice courts (also called justice of the peace or J. P. courts). In British Colombia Canada, Eviction, also known as "unlawful detainer", "summary possession", or "forcible detainer" in some jurisdictions, is the removal of a tenant from rental property by a law enforcement officer. Before a tenant can be evicted, a landlord must win an eviction lawsuit (Taribo, 2011). In some areas, landlords can evict their tenants without cause. In other areas, the law requires landlords to have a "just cause", which usually includes non-payment of rent or damaging the property. There is a general trend towards requiring just cause for eviction and this portends danger for efficient housing delivery (Carroll, 2008) In Nigeria, just cause is necessary for an eviction suit to favor the landlord (ACN, 2011; Lagos State Government, 2011; Nigeria Property Centre, 2012).

Eviction can be actual, constructive, partial or retaliatory in nature (Friedman et al, 1997; RHOL, 2006): Actual eviction exists where one is removed from the property either by force or process of law. When it is by the process of law it is called legal eviction (Aaron, 2003). It requires that a proper notice is served requiring the tenant to vacate the apartment within a specified time interval, and court process is used to follow up when the tenant dishonors the notice. Constructive eviction exists when, through the fault of the landlord, physical conditions of the property renders it unfit for the purpose for which it was leased. A tenant who has been constructively evicted has a number of legal recourses. He may be able to terminate the lease, order constructive eviction, and end liability for future rent payments (Burke and Snoe, 2008). Partial eviction exists where a tenant is deprived of a portion of the property for example, where a substantial modification is required on one side of the building, the landlord and the tenant may agree to a partial eviction from the property because of the disruption to be caused by the work. The tenant's rent will be reduced accordingly. Retaliatory eviction according to Aaron (2003) and RHOL (2006) occurs when a landlord attempts to evict a tenant in response to some (legal) action taken by the tenant. Eviction suit could be dismissed if the tenant provides reasons to convince the court that it is retaliatory. 


\section{The Study Area}

Ilorin is located on Latitude $8^{0} 30^{\prime} \mathrm{N}$ and Longitude $4^{0} 35^{\prime} \mathrm{E}$. It lies in the transitional zone of the middle belt and serves as a gateway city between the north and south-western part of the country. The city, which lies along LagosKaduna highway, is 306 kilometres from Lagos, 600 kilometres from Kaduna and about 500 kilometres from Abuja. Ilorin has a tropical wet and dry climate, and a mean rainfall of about $1318 \mathrm{~mm}$, which begins in April and ends in November.

Ilorin as a Yoruba settlement was founded in the 17th century by an itinerant hunter called Ojo Isekuse from Gambe near Oyo-lle (Taiwo, 2005). It consists of many tribes like Yoruba (the largest and the most popular), Hausa, Fulani, Nupe, Kanuri, Mali, Kamberi, Baruba and Futa (Taiwo, 2005). Unlike the others, The Futas are not Nigerians: they came from Sierra Leone. History has it that before the advent of the Fulanis, there was no single ruler over llorin other than the "Alaafin" of "Oyo". In fact, people from different places settled in Ilorin and each formed a hamlet headed by independent leaders.

When Alfa Alimi came to Ilorin from Sokoto in 1812; he was invited to head the town but he rejected the offer on the ground that his mission was purely religious. His eldest son was later invited to be the first Emir of llorin (Jimba, 1981). Since then the paramount ruler of the city and its environs (the llorin Emirate) is of Fulani origin although the royal house had been "Yorubanised" thoroughly and today, eleventh Emir is on the throne. The largest ethnic group in the city is Yoruba but the Fulanis hold a powerful political position. There is a large population of other Nigerians from other parts of the country who are mainly engaged in commercial and service sectors of the city's economy.

As at 1981, Kwara state had a total population of 1,714,485 while llorin alone had 208,546 constituting about $12.16 \%$ of the state population. The 1991 census provisional figure of population for the state was $1,566,469$ while the population figure for llorin metropolis was 508,388 (about 32.45\%). The 2006 population census figure revealed that there are 2,371,089 people in Kwara State with growing rate of 6.2\% ((NPC, 1991 and 2006; Odeniyi, 2007). Out of this, $1,012,894$ representing $42.72 \%$ of the state total population lives in llorin. The state capital is experiencing a very high rate of population growth over the time.

The metropolis is divided politically to form parts of five local government areas. One urban - llorin West Local Government and four rural - Ilorin East, Ilorin South, Moro and Asa Local Government Authorities. Each of these LGAs cuts across some parts of Ilorin metropolis but has its headquarters outside llorin except llorin West Local Government Authority, which has its headquarters at the heart of the city adjacent to the Emir's palace.

The earlier settlers in llorin engaged in primary activities like farming and hunting expedition and later Islamic education with arrival of Islamic scholars from Sokoto. This attracted a large concentration of people from different parts of the country. When the city became a state capital in 1967, the pace of commerce and public administration increased tremendously. Today, most residents are engaged in public and civil service working in the federal and state ministries, local government secretariats, educational institutions like the federal university, state polytechnic, secondary and primary schools, teaching hospital, federal research institutes and other places. A lot of private professional offices and artisans are also present in llorin. Presently, the economic base is now very expansive and extensive, and thus provided ample employment opportunity for school leavers, graduates, skilled and unskilled persons. All economic activities associated with urban areas in Nigeria are common in llorin.

The Ilorin property market can be classified into three viz: the residential, commercial and industrial property markets. Residential and commercial properties are the two main categories of properties in the management portfolio of the estate surveyors in the study area. The residential and commercial property markets are very active in llorin metropolis. The residential properties commonly found are tenement, block of flats, bungalow, detached house and duplex while the commercial properties are mainly shops and offices. There is little concentration of industrial properties as industrial development in the city is very low. Most of the industrial premises are owner-occupied and there are few cases of tenancy in industrial property, so the market is not quite active.

\section{RESEARCH METHODOLOGY}

The study population are the existing 16 practising and active firms of Estate Surveyors and Valuers within Ilorin metropolis during the period covered by the study. The study considered and surveyed the Managing Partners of the firms as representatives of their respective firms. It is expected that the Managing Partners would have greater experience of the theory and practical aspects of the profession. They would also have a better knowledge base regarding property management and tenant eviction. 
Essential primary data for this study include records of tenant evictions within the ten years which were collected by self-administered questionnaires administered on the estate surveying firms. The questionnaire was a combination of closed and open-ended questions.

The questionnaires were divided into three sections. The first section required information on demographic variables and background of the respondents. The second section asked questions on property management activities as related to how they carryout their management functions and observance of covenants under the tenancy. The third section required answers to questions relating directly to tenant eviction. All the questionnaires were retrieved and found useful for the study, giving a response rate of $100 \%$. Data collected were analysed with descriptive statistical methods mainly frequency distribution, tables and percentages.

\section{Data Presentation and Analysis}

This section presents the details of analysis of data collected from questionnaires administered on estate surveying firms in llorin metropolis. The main headings of presentation are demographic variables, trends of tenant eviction and categories of tenants affected.

\section{Demographic Variables and Background of the Estate Surveying Firms}

Table 1 reveals the responses of estate surveyors in relation to age group of respondents. It indicates that majority of respondents $9(56.25 \%)$ were above the age of 50 years; $4(25 \%)$ respondents were $41-50$ years of age; while only $3(18.75 \%)$ were between $31-40$ years of age. This indicates that the respondents are all adults who can appreciate the purpose of the research and so furnish relevant and reliable data for the study.

Table 1: Distribution of Surveyors According to age group

\begin{tabular}{|l|c|c|}
\hline Options & $\begin{array}{c}\text { Marginal Frequency } \\
\text { (Counts) }\end{array}$ & $\begin{array}{c}\text { Relative Frequency } \\
(\%)\end{array}$ \\
\hline $31-40$ Years & 3 & 18.75 \\
\hline $41-50$ Years & 4 & 25.00 \\
\hline Over 50 Years & 9 & 56.25 \\
\hline Total & 16 & 100 \\
\hline
\end{tabular}

SOURCE: Author's Field Survey, 2008.

Table 2 reveals the responses of estate surveyors in relation to positions held by respondents in their various firms. It reveals that the majority $10(62.5 \%)$ were the principal partners/ managing partners/ chief executives of their firms; $4(25 \%)$ were estate surveyors while $2(12.5 \%)$ were branch managers. This indicates that the data have been collected from the right persons in the various firms and that their responses are reliable and suitable for the study.

Table 2: Distribution of Surveyors According Positions in their firms

\begin{tabular}{|l|l|l|}
\hline Options & $\begin{array}{l}\text { Marginal Frequency } \\
\text { (Counts) }\end{array}$ & $\begin{array}{l}\text { Relative Frequency } \\
(\%)\end{array}$ \\
\hline Principal & 10 & 62.50 \\
\hline Branch Manager & 2 & 12.50 \\
\hline Estate Surveyor & 4 & 25.00 \\
\hline Total & 16 & 100 \\
\hline
\end{tabular}

SOURCE: Author's Field Survey, 2008

Table 3 reveals the responses of estate surveyors in relation to age of firm in the study area. The table reveals that $2(12.50 \%)$ firms have spent $3-5$ years in practice in llorin; $3(18.75 \%)$ firms have spent $6-10$ years in practice; 5 $(31.25 \%)$ firms have spent 11 - 15 years in practice in llorin; $3(18.75 \%)$ firms have spent $16-20$ years; and 3 $(18.75 \%)$ have spent more than 20 years in practice. This indicates that the firms are suitable to supply the required data for the study with respect to the ten years covered by the study. 
Table 3: Distribution of Surveyors According to Age of Firms

\begin{tabular}{|l|c|c|}
\hline Options & $\begin{array}{c}\text { Marginal Frequency } \\
\text { (Counts) }\end{array}$ & $\begin{array}{c}\text { Relative Frequency } \\
(\%)\end{array}$ \\
\hline $3-5$ Years & 2 & 12.50 \\
\hline $6-10$ Years & 3 & 18.75 \\
\hline $11-15$ Years & 5 & 31.25 \\
\hline $16-20$ Years & 3 & 18.75 \\
\hline Over 20 Years & 3 & 18.75 \\
\hline Total & 16 & 100 \\
\hline
\end{tabular}

SOURCE: Author's Field Survey, 2008

The table 4 reveals that the majority of the respondents $8(50 \%)$ have bachelor degree as their highest level of academic qualification. $5(31.25 \%)$ have HND as their highest level of academic qualification; while $3(18.75 \%)$ have additional academic qualification at masters level. One may deduce from this outcome that the respondents are qualified to know the importance of research and can be relied upon to give reliable information.

Table 4: Academic Qualifications of the Surveyors

\begin{tabular}{|l|c|c|}
\hline Options & $\begin{array}{c}\text { Marginal Frequency } \\
\text { (Counts) }\end{array}$ & $\begin{array}{c}\text { Relative Frequency } \\
(\%)\end{array}$ \\
\hline B.Sc & 8 & 50.00 \\
\hline HND & 5 & 31.25 \\
\hline M.Sc / MBA & 3 & 18.75 \\
\hline Total & 16 & 100 \\
\hline
\end{tabular}

SOURCE: Author's Field Survey, 2008

Furthermore, the surveyors were asked questions relating to the professional bodies to which they belong. Their responses documented in table 5, reveals that the majority $10(62.5 \%)$ respondents were associates of the Nigerian Institution of Estate Surveyors and Valuers (NIESV), 5 (31.25\%) respondents were fellows of the NIESV; while only $1(6.25 \%)$ respondents was a probationer of the NIESV. This result shows that the respondents are academically and professionally competent to give reliable data for this study.

Table 5: Professional Qualifications of the Surveyors

\begin{tabular}{|l|c|c|}
\hline Options & $\begin{array}{c}\text { Marginal Frequency } \\
\text { (Counts) }\end{array}$ & $\begin{array}{c}\text { Relative Frequency } \\
(\%)\end{array}$ \\
\hline Probationer & 1 & 6.25 \\
\hline ANIVS & 10 & 62.50 \\
\hline FNIVS & 5 & 31.25 \\
\hline Total & 16 & 100 \\
\hline
\end{tabular}

SOURCE: Author's Field Survey, 2008

Table 6 shows the scope of professional services of the surveyors in the study area. The table reveals that property valuation, property management and estate agency have 100 per cent each. This means that all the surveying firms carry out these services. It is also indicated that $8(50 \%)$ and $7(43.75 \%)$ firms engage in feasibility study and property development respectively. This result shows that all the firms are fully engaged in property management and estate agency which comprise tenant eviction practice. It shows that they are competent to give reliable data for the research. 


\begin{tabular}{|l|c|c|}
\hline Table 6: Scope of Professional Services \\
\hline Professional Services & $\begin{array}{c}\text { Marginal Frequency } \\
\text { (Counts) }\end{array}$ & $\begin{array}{c}\text { Relative Frequency } \\
(\%)\end{array}$ \\
\hline Property valuation & 16 & 100 \\
\hline Property management & 16 & 100 \\
\hline Property development & 7 & 43.75 \\
\hline Estate Agency & 16 & 50 \\
\hline Feasibility study & 8 & \\
\hline
\end{tabular}

SOURCE: Author's Field Survey, 2008

The responses of the estate surveyors in relation to the types of property managed by their firms as shown in table 7 reveals that $15(93.75 \%)$ of the respondents manage tenement buildings, while only $1(6.25 \%)$ firm does not manage tenement buildings. All the $16(100 \%)$ surveying firms had flats, bungalows and shops in their management portfolios. Furthermore, $13(81.25 \%)$ firms also had duplex in their management portfolios while only $3(18.75 \%)$ firms did not have duplexes in their management portfolios. More so, $6(37.5 \%)$ firms had detached houses in their management portfolios. Moreover, 14 (87.5\%) firms managed office buildings while only $2(12.5 \%)$ firms did not have offices in their management portfolio. This indicates that commercial and residential property markets are active in the study area.

Table 7: Distribution of the Surveyors According to Types of Property Managed

\begin{tabular}{|l|c|c|c|c|}
\hline \multirow{2}{*}{ Property Managed } & \multicolumn{2}{|c|}{ Yes } & \multicolumn{2}{c|}{ No } \\
\cline { 2 - 5 } & $f$ & $\%$ & $f$ & $\%$ \\
\hline Tenement & 15 & 15.63 & 1 & 6.25 \\
\hline Flats & 16 & 16.67 & 0 & 0 \\
\hline Bungalows & 16 & 16.67 & 0 & 0 \\
\hline Duplexes & 13 & 13.54 & 3 & 18.75 \\
\hline Detached & 6 & 6.25 & 10 & 62.50 \\
\hline Offices & 14 & 14.58 & 2 & 12.50 \\
\hline Shops & 16 & 16.67 & 0 & 0 \\
\hline Total & $96^{*}$ & 100 & $16^{*}$ & 100 \\
\hline
\end{tabular}

SOURCE: Author's Field Survey, 2008

*NOTE: This exceeds the number of questionnaires administered because of multiple responses.

\section{Trends of tenant eviction}

Table 8 reveals that eviction varies from year to year and from one residential property type to another for specific years. The total eviction has been on the increase generally especially from 2002 to 2007. Over the period of ten years, the highest number (590) of eviction was recorded in flats. This is closely followed by tenement buildings which recorded 561 evictions. Bungalows come next with 240 evictions and the least figure of 55 was recorded in duplexes. The variation is probably due to the fact that tenement and flats are mostly occupied by lower income earners. Bungalows and duplexes are mostly occupied by higher income earners. The lower income earners are more vulnerable to evictions than higher income earners. 
Table 8: The Trends of Tenant Eviction in Residential Properties (1998 - 2007)

\begin{tabular}{|l|c|c|c|c|c|c|c|c|c|c|c|}
\hline \multicolumn{1}{|c|}{ Property } & 1998 & 1999 & 2000 & 2001 & 2002 & 2003 & 2004 & 2005 & 2006 & 2007 & Total \\
\hline Tenements & 31 & 29 & 47 & 49 & 47 & 45 & 59 & 47 & 102 & 105 & 561 \\
\hline Flats & 53 & 55 & 67 & 64 & 53 & 53 & 56 & 54 & 67 & 68 & 590 \\
\hline Bungalows & 12 & 17 & 30 & 29 & 19 & 32 & 17 & 24 & 25 & 35 & 240 \\
\hline Duplexes & - & - & 6 & 7 & 5 & 6 & 1 & 7 & 12 & 11 & 55 \\
\hline \multicolumn{1}{|c}{ Total } & 96 & 101 & 150 & 149 & 124 & 136 & 133 & 132 & 206 & 219 & 1,446 \\
\hline
\end{tabular}

SOURCE: Author's Field Survey, 2008

Table 9 shows the eviction figures for the commercial properties. Like residential properties, the commercial properties also recorded irregular occurrence of eviction. Shops recorded higher figures (447) of eviction than offices (254). There are more shops in the market than offices and more shops are managed by estate surveyors.

Table 9: The Trends of Tenant Eviction in Commercial Properties $(1998-2007)$

\begin{tabular}{|l|c|c|c|c|c|c|c|c|c|c|c|}
\hline Property & 1998 & 1999 & 2000 & 2001 & 2002 & 2003 & 2004 & 2005 & 2006 & 2007 & Total \\
\hline Offices & 8 & 9 & 17 & 23 & 10 & 17 & 25 & 57 & 51 & 37 & 254 \\
\hline Shops & 32 & 24 & 51 & 44 & 51 & 42 & 45 & 64 & 36 & 58 & 447 \\
\hline Total & 40 & 33 & 68 & 67 & 61 & 59 & 70 & 121 & 87 & 95 & 701 \\
\hline
\end{tabular}

SOURCE: Author's Field Survey, 2008

\section{Graphical representation of the eviction figures showing the trends (1998 - 2007)}

\section{The Trends of Eviction (1998 - 2007)}

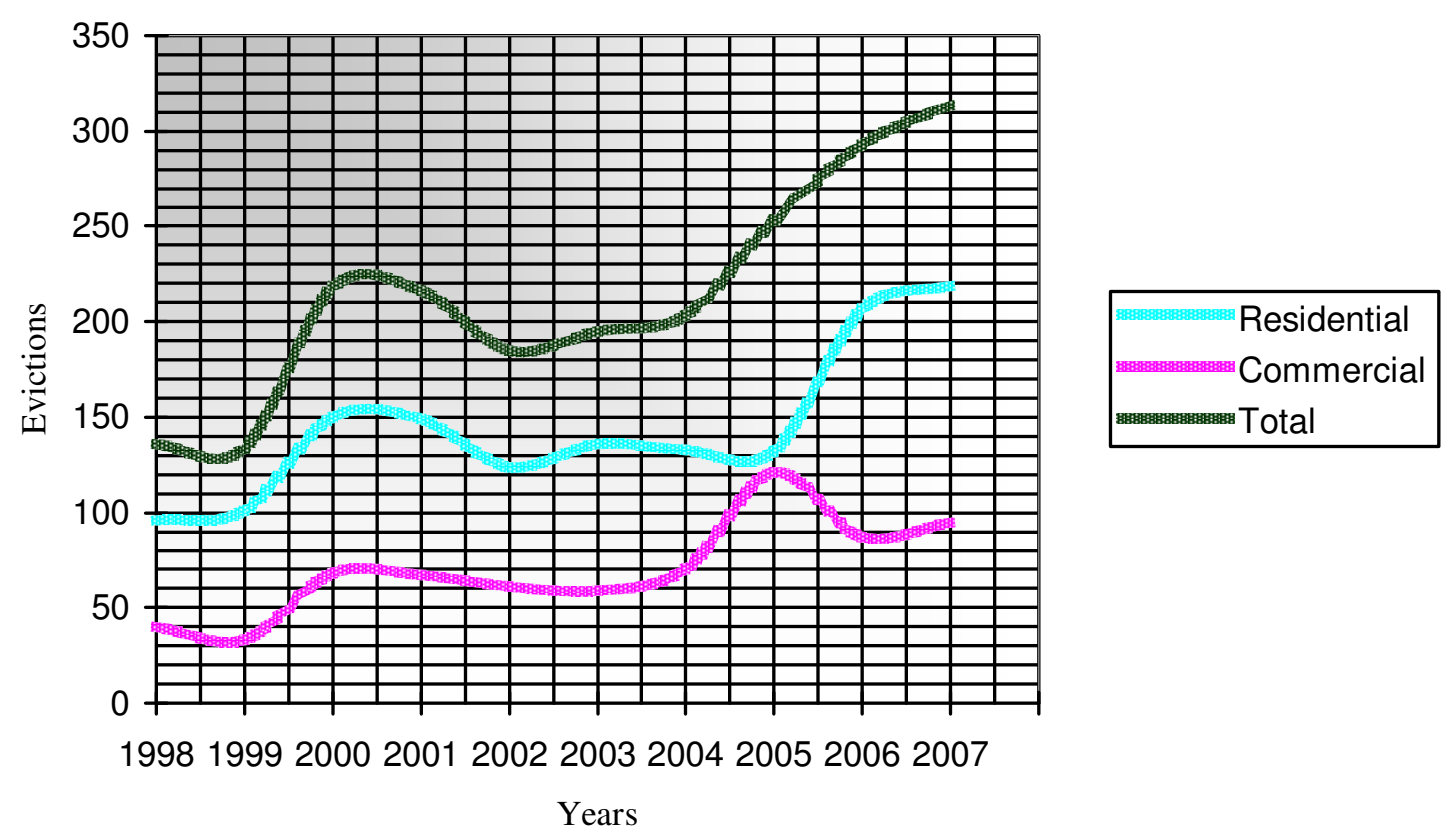




\section{Categories of Tenants Affected by Eviction}

The surveyors were asked to select the categories of tenants mostly involved in eviction from a list of the three income brackets which are non-mutually exclusive. Their responses shown in table 4.10 revealed that the largest relative counts $15(51.72 \%)$ stated low income group. The category that comes next is the medium income group 11 $(37.93 \%)$ and high income group having the least frequency count of $3(10.35 \%)$. One can infer from this that although eviction affects all categories of tenant, its incidence is higher on the low income group.

Table 10: The Categories of Tenants Affected by Eviction

\begin{tabular}{|l|l|l|l|}
\hline Tenant Category & $\begin{array}{l}\text { Marginal Frequency } \\
\text { (Counts) }\end{array}$ & $\begin{array}{l}\text { Relative Frequency } \\
(\%)\end{array}$ & Rank \\
\hline Low income group & 15 & 51.72 & 1 \\
\hline Medium income group & 11 & 37.93 & 2 \\
\hline High income group & 3 & 10.35 & 3 \\
\hline Total & 29 & 100 & \\
\hline
\end{tabular}

SOURCE: Author's Field Survey, 2008

\section{SUMMARY AND CONCLUSION}

It was discovered that between 1998 and 2007, the incidence of tenant eviction was higher on residential properties while low income earners residing in tenement and block of flats are mostly affected. Other residential property tenants affected are those evicted from bungalows and duplexes. A substantial number of commercial property (shop and office) tenants were also evicted during the period. Other categories of evicted tenants are low and medium income group and few high income group. Results showed that evictions from residential properties accounted for $67.35 \%$ while commercial properties accounted for $32.65 \%$. There were increasing trend in eviction during the period. It increased from 136 in 1998 through the years to 2,147 in 2007.

The qualitative and quantitative housing problems remained substantial in Nigeria. Eviction is a hidden problem that confronts many and constitutes a major problem for most productive men and women in the society. The implication here is that many residents live in constant fear of eviction and this represents traumatic living condition which will have negative impact on real productivity of average persons involved. It is observed that necessary action should be taken to reduce the incidence evictions, which is higher in residential properties and disproportionately affected lower-income tenants.

Evictions are not always bad, it can benefit individuals especially the landlord in that bad tenant can be evicted to pave way for selecting a better one who will pay higher rents, carryout proper maintenance of the property, live amicably with neighbours and have respect for the terms of the tenancy. It is true that the current legal system protects the legitimate interests of tenants. It is necessary to note that the problem is not the eviction itself but the potential outcome for individual stakeholders. Hence, this calls for urgent attention of the government at various levels to bring succour to the practice, the tenants, landlords and the property managers.

\section{REFERENCES}

Aaron, L. (2003): "So You Are Being Evicted? Tips for Tenants"..Expertlaw articles, Retrieved July 28, 2013 from http://www.expertlaw.com/library/real-estate/evicted-tenant.html

ACN (2011). What The New Lagos Tenancy Law Says. Accessed on 30/9/2012 at http://actioncongress.org/category/news/article

Burke D.B. and Snoe J.A. (2008). Disturbed Tenant: A Constructive Eviction in Property: Examples \& Explanations - Page 312 - Google Books Aspen Publishers, Accessed on 25/3/ 2013 at books.google.com.ng/books?isbn= 0735570310

Carroll A.B. (2008). International Trend Toward Requiring Good Cause for Tenant Eviction: Dangerous portent for the US; Seton Hall Law Review, Vol. 38; p.427. Available at SSRN: http://ssrn.com/abstract=1401605

COHRE (2004): "Housing Rights for Everyone, Everywhere". Evictions Monitor Vol. 1 No. 2 December. Retrieved March 03, 2007, from http://www.cohre.org

Friedman, J.P., Harris, J. C. \& Lindeman, J. B. (1997): Dictionary of Real Estate Terms; 4th Edition; Baron's Education Series; New York. 
Ibrahim, T.A. (2010): A Study of Tenant Eviction Practice in Property Management in llorin Metropolis between 1998 - 2007; An Unpublished Thesis Submitted to Obafemi Awolowo University, Ile - Ife for MSc Degree in Estate Management.

Jimba, S. (1981) A Short History of llorin. Jimba Books Production Company, llorin.

Knowsley Council (2013) Housing Advice for Private Sector Tenants: A guide to how to resolve your housing difficulties if you rent your home from a private landlord. Accessed on 6/6/2013 from www.knowsley.gov.uk

Lagos State Government (2011). Lagos Tenancy Law 2011; Ikeja. Accessed on 12/02/2013 at http://www.nigerialaw.org/Legislation/Laws of the States

Landlord and Tenant Board (2012). How a Tenant Can End Their Tenancy. Accessed on 29/09/2012 from Http://www.Itb.gov.on.ca/key_information

Langston, H. (1951): "The Concept of Landlord: A Short History from Medieval Times to the Present"; In Landlords: History \& Concept; Harvard University.

Leckie S. (1995): When Push Comes to Shove: Forced Evictions and Human Rights. Habitat International Coalition; Utrecht, Netherlands.

MBIE (2013). Ending Tenancies Frequently Asked Questions; Accessed on 30/02/2013 at http://www.dbh.govt.nz/tenancy-index.

Moneke, F (2009). Nigeria: Landlord \& Tenant - The Right to Shelter and Statutory Protection of Tenants. Accessed on 30/02/2013 at www.allafrica.com

Nottingham City Homes (NCH) (2012) Tenancy Sustainment Strategy 2012-15. Accessed on 13/01/2013 at http://www.nottinghamcityhomes.org.uk/documents/about_us/performance_and_service_improvement

Nigeria Property Centre (2012). How to Recover Residential Premises from Tenants in Lagos State, Nigeria. Accessed on 30/02/2012 at www.nigeriapropertycentre.com/blog/author/administrator. NPC (1991). Povisional Census Figures; Lagos. NPC (2006). Provisional Census Figures; Abuja.

Odeniyi P. (2007): "Census 2006: North is $75 \mathrm{~m}$, South 64m". In The Nation Newspapers, Volume 1, No 0164 , January 10.

Ojo, O. (2007): "Tenant Eviction Methods in Residential Property Market in Ibadan Metropolis". In Fadare W. and Adesanya A. (eds) ("2007): Towards a Sustainable Built and Natural Environment; Faculty of EDM Conference Paper, OAU, Ile-Ife.

Powel R. (1969) Landlord and Tenant: Implied Warranty Of Habitability Derived From Contract Principles In The Law of Landlord-Tenant: A Critical Evaluation of the Past with Guidelines for the Future, Quinn \& Phillips, 38 Fordham Law Review http://digitalcommons.law.Isu.edu/cgi/viewcontent.cgi?article=4950\&context=lalrev

Rental Housing On Line (2006): "Members Eviction Information". The Internet Comprehensive Rental Property Location; USA. Retrieved March 10, 2006, from www.rhol.com

Spitzer E. (2006): "Tenant's Rights Guide". Office of the New York State Attorney General, New York. Retrieved February 17, 2007, from www.oag.state.ny.us

Taiwo, S.A (2005): Enlefaa - A Radio Entertainment Programme in llorin Dialect. Tajudeen Printing Press; llorin.

Taribo B.A. (2011) (ed.). Recovery of Premises In Nigeria: A Summary Review, The Legal Luminary; Volume 1, Issue 10 September. Accessed on 30/02/2013 at www.ndic.org.ng/../luminary-September

Texas Low Income Housing Information Service (2013): "Texas Tenant Advisor: Know your rights as a tenant in Texas". Available on 27/7/2013 at http://www.texashousing.org/

The Legal Assistance Resource Center of CT, (2013): "Tenants' Rights: Eviction”. Retrieved July 27, 2013, from www.larcc.org/ 